\title{
Varieties of English and Kachru's Expanding Circle
}

\author{
Zoya G. PROSHINA ${ }^{1}$ and Cecil L. NELSON ${ }^{2}$ \\ ${ }^{1}$ Lomonosov Moscow State University \\ Moscow, Russia \\ 2 Indiana State University \\ Terre Haute, Indiana, USA
}

\begin{abstract}
In this overview article, we present the motivations for compiling this issue of $R J L$ and summarize the major premises of the World Englishes (WE) Paradigm. The focus is on the relations between the WE school of thought and the paradigms that branched from it, i.e. English as a Lingua Franca (ELF) and English as an International Language (EIL). The statuses of Englishes in the Kachruvian Expanding Circle that function mainly as lingua francas in international communication is one of the most controversial issues in sociolinguistics. We discuss the misconceptions regarding the Expanding Circle Englishes. Finally, we give a brief survey of the articles contributed to this issue, which develop theoretical and empirical material for the WE paradigm.

Keywords: World Englishes paradigm, varieties, Expanding Circle, English as a Lingua Franca, English as an International Language, International English, language norms

\section{For citation:}

Proshina, Zoya G. \& Cecil L. Nelson. 2020. Varieties of English and Kachru's Expanding Circle. Russian Journal of Linguistics 24 (3). 523-550. DOI: 10.22363/2687-0088-2020-24-3523-550
\end{abstract}

Вступительная статья

\section{Варианты английского языка и Расширяющийся круг Качру}

\section{3.Г. ПРОШИНА ${ }^{1}$, С.Л. НЕЛЬСОН ${ }^{2}$}

${ }^{1}$ Московский государственный университет имени М.В. Ломоносова

\author{
Москва, Россия \\ 2 Университет штата Индиана \\ Teppe-Xom, США
}

\begin{abstract}
Аннотация
В данной обзорной статье объясняются причины, обусловившие подготовку этого выпуска журнала, и суммируются основные положения контактной вариантологии английского языка. Обращается внимание на связь между парадигмой, изучающей варианты английского языка в мире, и теориями, отпочковавшимися от нее - теорией английского как лингва франка и теорией английского как международного языка. Одной из самых спорных проблем социолингвистики стал вопрос о статусе вариантов из Расширяющегося круга,
\end{abstract}


представленного в теории Б. Качру. В международной коммуникации эти варианты функционируют главным образом как языки-посредники, или лингва франка. Рассматриваются ошибочные концепции относительно вариантов Расширяющегося круга. В заключение делается краткий обзор статей, представленных в данный номер, развивающих теорию и предоставляющих эмпирический материал для дальнейшей разработки теории вариантов английского языка в мире.

Ключевые слова: контактная вариантология английского языка, варианты, Расширяющийся круг, английский как лингва франка, английский как международный язык, международный английский язык, языковые нормы

\section{Для цитирования:}

Proshina Z.G., Nelson C.L. Varieties of English and Kachru's Expanding Circle. Russian Journal of Linguistics. 2020. Vol. 24. № 3. P. 523-550. DOI: 10.22363/2687-0088-2020-24-3523-550

\section{Introduction}

This journal issue is a collection of articles that ponder the status, functions, and features of Englishes that in their home settings are mostly known as a foreign language. They are normally used for intercultural communication with people of other countries and rarely for interpersonal communication within their own countries. These varieties of English belong to the third group of Englishes that are regularly named Expanding Circle Englishes in the famous Three Circles Theory of Braj B. Kachru (1985). The other two groups are termed Inner Circle Englishes, characterized as native (first) languages for the majority of their countries' populations and serving almost all possible functions within their communities, and Outer Circle Englishes, institutionalized and serving as a second official (co-official) language in their country's institutions. (Critiques of Kachru's model and descriptions of other models are examined in Schneider 2017 and Berns 2019.)

According to the statistics provided by ThoughtCo ${ }^{1}$, English as a Second Language is learned by 375 million people, while English as a Foreign Language is learnt by 750 million (Beare 2020). Thus, there are twice as many users of English in the Expanding Circle as in the Outer Circle. In China only, in 2001 the number of English learners was 390 million (Wei \& Su 2012: 11). Statistics provided by Levada-Center reveal that in $2014,11 \%$ of Russians, about 16 million users, claimed good knowledge of English.

The quantitative research conducted by Margie Berns in 2005 and 2019 demonstrated steadily growing interest in Expanding Circle Englishes. Berns counted papers published in two scholarly journals, World Englishes and English Today, and found that within the period of 1998-2001 these journals published 47 articles on Expanding Circle Englishes. In 2001-2018, the number of papers on Expanding Circle Englishes was 318. The total number was 365 papers covering 79 countries and 11 regions, with the "lion's share" (Berns 2019: 12) relating to East Asia, especially China (about 100 papers) and Japan (20 papers). Russian

\footnotetext{
${ }^{1}$ ThoughtCo is a premier reference education site, whose content is created by high-grading experts in a field. See https://www.thoughtco.com/about-us (accessed: 16.07.2020).
} 
English was documented in 19 articles, the majority of which were published in a special issue of World Englishes (Proshina 2005). Berns stressed that these Expanding Circle Englishes "remain uncharted territory in many respects" (Berns 2019: 13).

In fact, the proof of her statement can be seen even in such encyclopedic reference works as handbooks. The first Handbook of World Englishes, published in 2006 (Kachru, Kachru \& Nelson 2006), had only three chapters on Expanding Circle varieties - East Asian, South American, and European Englishes - of sixteen chapters describing localized world Englishes. The second edition of the Handbook of World Englishes (Nelson, Proshina \& Davis 2020) has five chapters dealing specifically with South American, European, Russian, East Asian, and Chinese Englishes. Five chapters on East Asian, Chinese, Slavic, Colombian, and European Englishes are included in The Routledge Handbook of World Englishes (Kirkpatrick 2010). Only one region (Central America) of the Expanding Circle is covered in The Cambridge Handbook of World Englishes (Schreier, Hundt \& Schneider 2020), and three in The Oxford Handbook of World Englishes (Filppula, Klemola \& Sharma 2017). Seven regional varieties are discussed in The Routledge Handbook of English as a Lingua Franca (Jenkins, Baker \& Dewey 2018). Though Thumboo's volume titled The Three Circles of English (Thumboo 2001) is aimed at discussing various Englishes that are comprised in the Kachruvian model, only four chapters address the Expanding Circle proper. Very little information on the Expanding Circle can be found in A Dictionary of Varieties of English (Hickey 2014).

Special works on Expanding Circle Englishes are not numerous, either. European Englishes are examined in Cenoz \& Jessner (2000), Görlach (2001, 2002), Berns, de Bot \& Hasebrink (2007), Houwer \& Wilton (2011), Edwards (2016), Borodina (2018). East Asian Englishes are researched in Proshina (2001, 2020); Bolton (2003), Stanlaw (2004), Bondarenko (2007), Bianko, Orton \& Gao (2009), Ivankova (2009), Seargeant (2009, 2011), Xu (2010), Zavyalova (2011), Graddol (2013), Hadikin (2014), Cho (2017), and Jenks \& Lee (2017).

Russian English, though a very debatable issue, has been a focus of the special volume Russian English: History, Functions, and Features (Proshina \& Eddy 2016), as well as a number of articles (Gritsenko 2014, Proshina 2006, 2014b, Proshina \& Rivlina 2018, 2020, Rivlina 2013, 2015a, 2015b, Ustinova 2005, 2006) and dissertations (Eddy 2007, Lawrick 2011, Lazaretnaya 2012). Some authors, though not using the term 'Russian English' have in fact contributed to the discussion of the variety, its cultural underpinning (Kabakchi 1998, 2002, 2015) and its linguistic features (Savitsky \& Kurovskaya 2004, Schennikova 2017, Shishkina 1996).

Given what has been said and still is to be clarified, the motivation of this journal's thematic issue is the need to discuss the nature of Expanding Circle Englishes and the factors that facilitate their development, different from each other and from other varieties in the Inner and Outer Circles, yet not recognized by many 
speakers of these varieties or even by linguistic scholars who, on the one hand, take Kachru's division of world Englishes for granted, but on the other, argue against Expanding Circle Englishes having the right to be called a variety.

\section{The WE paradigm and how it differs from other theories}

Before we introduce the articles contributed to this issue, we would like to remind the reader of the major prerequisites and tenets of the Word Englishes (WE) paradigm, and its connection with other paradigms that have actually branched from it.

The WE paradigm, which emerged in the 1960s (Kachru 1961, Beliayeva \& Potapova 1961) and has developed since, with its theoretical basis brought into focus especially in the 1980-1990s (Kachru 1986, Kachru \& Smith 1985, Smith 1987, Smith \& Forman 1997, see also Bolton 2020), is a revolutionary theory (Proshina 2014a), as it has radically challenged the traditional views on the Empire's linguistic dominance, flipped sociolinguistic ideas, and drastically changed pedagogical beliefs that had found their way into English language teaching and learning. To summarize the major premises, the following arguments should be highlighted:

- English is not a monolithic and homogeneous language anymore. Being pluricentric (which is due to historical, political, and economic, as well as cultural and informational reasons), it has differentiated into a great number of varieties world Englishes.

- Each variety is underpinned by its linguaculture, which means it is able to express the cultural identity of its users and has certain features transferred from their mother tongues and/or other languages that are in regular contact with this variety.

- A variety is a sociolinguistic phenomenon. Therefore, it has features characteristic of a certain speech community on the average but not necessarily manifested in the speech of every member of this community, since each speaker's usage depends on the level of language proficiency, sphere of use, style of communication, and individual preferences.

- Due to the linguacultural underpinning that identifies each variety, world Englishes are all equally legitimate. In the very first issue of the World Englishes journal, its founding editors stated:

The editorial board considers the native and non-native users of English as equal partners in deliberations on users of English and its teaching internationally. $W E$ is thus a vehicle which may be used to share the vast Western and non-Western expertise and experience for the benefit of all users of English.... The acronym $W E$, therefore aptly symbolizes the underlying philosophy of the journal and the aspirations of the Editorial Board (Kachru \& Smith 1985: 211).

- Varieties of the Outer and Expanding Circles are used as additional or auxiliary (Smith 1976) communicative tools. The functions of the burgeoning 
varieties might seem restricted, but the more a variety develops over time, the more functions it gains. Kachru (1986: 92) refers to the ranges of Englishes in "cultural, social, educational, and commercial contexts," and to the depths of their social acceptance and use in "various strata of society." This dynamic headway is nowadays obvious in all varieties.

These innovative features are salient for linguistics, especially sociolinguistics, literature studies, culture studies, and applied linguistics, by which we understand not only the domain of language teaching and learning as is normally meant "in the Anglophone literature" (Knapp \& Antos 2009: vii), but also in the so-called "Practical Applied Linguistics" in Back's sense of the term (Back 1970), as it is also used in Russia, i.e., "application of insights from linguistics in a practical field related to language, such as language teaching, translation, and the like" (Knapp \& Antos 2009: vii). In a word, these features mark the interdisciplinarity of the new paradigm, which makes it much wider in its scope than the English as a Foreign Language (EFL) paradigm in English language teaching (ELT).

The WE paradigm has led to the emergence of other branches of research that are nowadays characterized as new paradigms - English as an International Language (EIL) and English as a Lingua Franca (ELF) - that are developing certain aspects related to world Englishes. Both these branches have ELT as their major focus. They stand in clear opposition to the pedagogy of EFL, which is based on teaching a monocentric or bicentric model of English, based on British English and British culture, or/and American English and the culture and values it serves.

Unlike the pedagogical concept of EFL, the idea that stands behind EIL, the term put forward by Larry Smith (1976) and further developed by Farzad Sharifian (2009) and many other scholars (Alsagoff 2012, Marlina \& Giri 2014, Matsuda 2012, 2017, McKay 2002), focuses on the necessity of acquainting students with the language by exposing them to diverse world Englishes that might meet the needs of future communicators in real-life situations:

EIL in fact rejects the idea of any particular variety being selected as a lingua franca for intercultural communication. EIL emphasizes that English, with its many varieties, is a language of international, and therefore intercultural, communication. (Sharifian 2009: 2)

If the concept of EIL is grounded on the diversity of world Englishes, a similar term, International English, implies a controversial phenomenon. It is associated with an allegedly unified standard English that facilitates international communication (Todd \& Hancock 1987, Trudgill \& Hannah 1994) - similar to Quirk's idea of "nuclear English" (Quirk 1982) - and is used in formal contexts (though, as we will discuss later, it is an abstract ideal implemented in real speech practice with at least a local accent, if not other context-specific features). This understanding of International English coincides with Peter Strevens's definition: "a particular dialect of English, being the only non-localized dialect, of global currency without significant variation, universally accepted as the appropriate educational target in teaching English; which may be spoken with an unrestricted 
choice of accent" (Strevens 1983: 88). In fact, nowadays it is impossible to speak about one and the same standard of English for all varieties - they are changing dynamically and the process of standardization is observed in all of them (Hickey 2013). Judging by Strevens's definition, EIL and International English prove to be antonymic concepts, with EIL oriented towards diversity and differentiation i.e. varieties - and International English, towards unity and homogeneity, i.e. invariant.

The concept of English as a Lingua Franca (ELF) was revived by Alan Firth $(1990,1996)$ to imply "the modus operandi" for interactants none of whom has this language as their mother tongue (Firth 1996: 255). As is clear from this definition, native speakers are excluded from this conceptualization, which can reasonably be questioned, since speakers of English as their first language have to adapt the way they speak in intercultural settings. Therefore, nowadays more commonly accepted is the definition given by Barbara Seidlhofer: ELF is "any use of English among speakers of different first languages for whom English is the communicative medium of choice, and often the only option" (Seidlhofer 2011: 7), which includes participants of the three circles (though still we can find associations of ELF mostly with varieties of the Expanding Circle). Seidlhofer's explanation of ELF also prompts a very important conceptual idea: ELF is the use or function of any variety of English. It has no status as a variety, but is just a variety's pragmatic facet. Any world English as a variety (including Inner Circle varieties) can be characterized by this function, which is implemented mostly in intercultural communication. But besides this function, world Englishes have many other functions as well.

It is no wonder that when teachers are talking about ELF, they concentrate mostly on three objects: strategies of communication, mutual understanding, and diversity awareness.

Firstly, strategies of communication are aimed at mutual accommodation of speakers via such adaptive processes as exploiting redundancy, regularization, added prominence, explication, adjustments, reformulations, repetition, codeswitching, negotiation of meaning, and many others (Cogo \& Dewey 2012, Mauranen \& Ranta 2010, Meierkord 2012, Vettorel 2018). Research on these processes is mainly carried out by means of corpora; therefore, the contributions of these scholars to corpus linguistics is undeniable (e.g., VOICE, Vienna-Oxford International Corpus of English; ELFA, English as a Lingua Franca in Academic Settings; CASE, Corpus of Academic Spoken English; ACE, Asian Corpus of English; RACE, Russian-Asian Corpus of English; BELF, English as Business Lingua Franca).

Secondly, mutual understanding in international communication is a common problem for ELF, EIL, and WE researchers. In the early days of the WE paradigm, the problem was formulated as a three-facet phenomenon by Larry Smith and the scholars he was working with (Nelson 2011, Smith 1992, Smith \& Bisazza 1982, Smith \& Rafiqzad 1979, Smith and Nelson 2020). Mutual understanding comprises three facets: intelligibility, understanding spoken and written forms of speech 
production; comprehensibility, understanding the meaning of what is said and written; and interpretability, understanding the sense of what hides behind the text a pragmatic component associated with the background knowledge of communicators which allows them to understand the purpose of the language in use.

The third challenge, diversity awareness, which is much discussed by ELF researchers (Bayyurt \& Sifakis 2015, Lopriore \& Vettorel 2015, Sifakis et al. 2018, Sung 2018, Wang 2015), is not an uncommon topic for EIL and WE scholars, as well. As was shown above, diversity has become a key word for talking about EIL. World Englishes are singled out based on different features and functions, and because of that, they are differentiated as varieties. From a pedagogical point of view, raising awareness of the diverse ways people speak English due to their different linguacultural grounds is to make "an informed choice" (Jenkins 2007: 22). which is necessary for effective intercultural communication.

An issue that seems to have been a stumbling block between ELF and WE supporters is the relation between ELF and a variety. Though it has been recognized that ELF "does not exist as a system" (Canagarajah 2007: 926) and "emerges out of and through interaction" (Meierkord 2004: 129, see also Kecskes 2019), and that it is an abstraction, a concept of a function but not a live variety per se (Berns 2009: 196), time and again we can find works (e.g., Breiteneder 2009, Mackenzie 2014, Jenkins 2017) that describe phonetic, syntactic, and other levels of ELF that demonstrate that the authors treat this concept as a structured variety (at least a generalized entity, which makes it an abstraction rather than a live phenomenon) instead of talking of world Englishes functioning as ELF.

\section{Dispelling doubts about the Expanding Circle}

While Inner Circle varieties, both old and new (like New Zealand, Australian, and Canadian Englishes), and many Outer Circle Englishes are well recognized and by now have been thoroughly described, the Expanding Circle Englishes have not yet been unanimously accepted, especially among their own users. Reasons for that are usually seen in these varieties not being codified, but if we have a deeper look into the problem, we can find that, in fact, the rationale for rejecting Expanding Circle varieties is lack of linguacultural acceptance.

Regarding codification, which is usually understood as the process resulting in standardization of the language, we can definitely argue that all varieties as language manifestations are standardized, though their spoken performance might be represented as either fitting norms or breaking them. Following Davis (2010), we use the term standardized English rather than standard English to emphasize the dynamic linguistic changes that take place in all world Englishes, including those that belong to the Inner Circle.

Speaking about types of language norms, Kachru (1985) subdivided them into three kinds according to the three circles: the Inner Circle comprises endonormative varieties that usually serve as norm-providing models for other Englishes; the Outer 
Circle varieties are in the most dynamic process of modifying the norms and, therefore, are considered as norm-developing Englishes; and the Expanding Circle varieties are norm-dependent and apply exonorms that have been developed and codified in other Englishes, not necessarily in the Inner Circle; if there is need, Expanding Circle users of English can employ standards of an Outer Circle English. The variability of exonorms, especially British and American, leads to their frequent mixture and results in a certain specificity in using the standardized variety.

As for speech production in Expanding Circle Englishes, Kachru's theory again provides us with an explanation in the form of a bilingual cline model (Kachru 1983). Any variety produced by contact with an indigenous language results in bilinguality of its users, which can be represented as a continuum of use, depending on the language competence of users and functions and style of their discourse. Acrolectal speech characterizes formal discourse of very competent uses; mesolectal speech is mostly manifest in informal discourse of educated speakers or in formal and informal discourse typical of users with less proficiency; and basilectal speech as a hybrid and even pidginized type of discourse is characteristic of uneducated users (Proshina 2017: 150-152).

We see that standardization should not be regarded as a major argument for accepting a variety, which exists in both standardized and non-standardized forms and includes not only acrolect, but also mesolect and basilect. Acceptance of a variety is gained when its users recognize that their variety expresses their linguacultural identity, and it might be a primary or a secondary vehicle for this expression. The variety they speak and write expresses their culture, values, mindset, and world view. This conceptual cultural part of identity is revealed through lexis and syntax, first and foremost (culture-loaded words, collocations, and syntactic structures). Besides these means, the lingual part of one's identity is also transferred via phonetic (phonetic accent) and grammatical levels (grammar categories, such as discretion in expressing plurality of nouns - equipments, furnitures - as is observed in Asian Englishes). The linguistic features result from transfer from the users' first language, as well as from verbalization of their mindset. For example, even in acrolectal Russian English one can hear Russian intonation, devoiced final consonants, frequent lack of aspiration, sometimes specific pronunciations of separate sounds (such as $t h, w, r$ ), by all of which the Russian accent is easily identified. On the grammatical level, direct object fronting (This book I haven't read yet.), lack or unusual use of articles (the complex ethnical structure of the population determines peculiarity of the gender interaction), avoidance of the Perfect tenses (I am living in this city since childhood), substitution of left-hand attributive clusters by postpositional attributes containing prepositions (Old English period > period of Old English), dominance of impersonal sentences with a dummy subject (It is expected that she will come will be preferred to She is supposed to come) are very typical. Many other features of Russian English discourse are described in Proshina \& Eddy (2016). 
This does not mean that absolutely all users of a variety will exhibit the full set of features typical of the variety. As has been mentioned, the number of the variety's distinctive features in an individual's spoken discourse will depend on the user's language competence, context of situation, state of mind, and degree of desire to follow the educational model as an exonorm.

Acceptance of a variety is a long process - it takes time for an English in a certain location to become the local English. Even Inner Circle Englishes, for example, Australian English, had to make the transition from English in Australia to Australian English (Fritz 2007) that was fully recognized as a variety per se only in the 1970s when Australians overcame their cultural cringe, and their cultural nationalism paved the way to assert their linguistic and cultural identity.

Social and psychological awareness of linguacultural identity expressed through a variety, as well as its educational codification (Kachru 1985), lead to recognizing its distinctive features. Most of the Expanding Circle varieties are still on their way to this recognition.

This recognition will certainly come with a growing functional increase of Expanding Circle Englishes. Nowadays they serve not only intercultural functions as a lingua franca. They also have informative functions in business, advertising, mass media, and science. They implement an instrumental function in education, including English as a medium of instruction (EMI). Expanding Circle Englishes can also be found in their creative functions (in translingual or contact literatures, mass culture, and ludic uses in puns and so on; see, for example, Seidlhofer (2010) for the functions of English and domains of its use in Europe).

To conclude, we would like to emphasize that Expanding Circle varieties do exist in real life and no matter how closely their users might approach an educating exonormative model, varieties will still have their own distinctive features as they serve as secondary means of linguacultural identity. A variety is a typical collection of discourse events and products, distinctive in linguistic features and cultural underpinnings.

A variety is not a simulation of a codified education model, nor is it a collection of defective speech samples of interlanguage. Expanding Circle varieties, like all other world Englishes, are used by educated communicators with fluent performance and high competence - those whom Kachru (1998) described as functional native speakers of their varieties (see also Smith 2008).

World Englishes of the three circles should constitute part and parcel of EIL curricula. Raising awareness of the diversity of Englishes is of unquestionable value in language teaching and learning and in translation and interpretation. The domain of applied linguistics is yet to be enriched by WE research. Knowing distinctive features of other varieties, as well as specifics of their Romanization systems (such as Chinese Pinyin, for example) will make intervarietal communication, including intervarietal translation, easier.

Recognizing one's own variety as a vehicle to express one's mindset and culture. and being aware of its place among other world Englishes provides 
psychological comfort in intercultural communication due to the principles of inclusiveness and equality of varieties. Knowing typical features of one's own variety is important for improving one's language competence.

\section{Brief description of this issue}

Berns (2005: 92) spoke about the "dawning age of the Expanding Circle Englishes." The publication of this issue of the Russian Journal of Linguistics shows that the dawn has gradually grown into late morning, though the primetime noon is still ahead.

Having described the motives that pushed us to collect this issue and the major premises of the WE paradigm and its branches, such as EIL and ELF, we would like to express our gratitude to the authors who contributed their works to make this publication interesting and insightful.

As readers can see from the Table of Contents, the articles presented in this journal deal with Asian (Japanese and Chinese), European (German), and Russian Englishes. They cover general issues of the Expanding Circle Englishes, their statuses, features, and functions (A. Kirkpatrick, V. Zavyalova, Zh. Xu \& D. Zhang, A. Rivlina, E. Gritsenko \& A. Alikina, and Yu. Davydova). Some of the articles discuss pedagogical challenges related to teaching global and local Englishes (J. D'Angelo \& S. Ike, N. Hino, and I. Lebedeva). One article (G. Lovtsevich \& A. Sokolov) examines the lexicographic aspect of WE as viewed from the Expanding Circle.

Besides the research articles, this issue also includes two reviews related directly to the theme of World Englishes (E. Marinina and E. Lebedeva).

All the problems are discussed from international perspectives, as the authors have worked in different parts of the world and synthesized their empirical research with in-depth theoretical foundations. We hope that readers will find the issues raised in these papers to be useful and stimulating food for thought, further research, and practical activities.

\section{RU}

\section{1. Введение}

В этом номере журнала собраны статьи, авторы которых размышляют о статусе, функциях и чертах вариантов английского языка, которые у себя на родине чаще всего называются иностранным языком. Обычно эти варианты используются для межкультурной коммуникации с представителями других стран и редко - для межличностного общения внутри своих стран. Эти варианты английского языка относятся к третьей группе, обычно называемой вариантами Расширяющегося круга, согласно известной теории трех кругов мирового английского языка Браджа Б. Качру (Kachru 1985). Две другие группы относятся к вариантам Внутреннего круга, которые характеризуются 
как родные (первые) языки для большинства населения этих стран и выполняют практически все возможные функции в рамках своего социума, и к вариантам Внешнего круга, которые институциализированы и выполняют роль второго официального языка в соответствующих институтах своих стран. Критика модели Б. Качру и описание других моделей рассмотрены в работах Э. Шнайдера (Schneider 2017) и М. Бёрнс (Berns 2019).

Согласно статистическим данным, предоставленным "ThoughtCo", английский как второй язык изучают 375 млн человек, в то время как английский как иностранный язык изучают 750 млн человек (Beare 2020). Таким образом, пользователей английского языка в Расширяющемся круге в два раза больше, чем во Внешнем круге. Только в Китае в 2001 г. число изучающих английский язык составляло 390 млн (Wei \& Su 2012: 11). Статистические данные, предоставленные Левада-центром, свидетельствуют, что в 2014 г. $11 \%$ россиян, т.е. около 16 млн человек заявляли о хорошем знании английского языка.

Количественное исследование, проведенное Марджи Бёрнс в 2005 и 2019 гг., показало стабильно растущий интерес к вариантам Расширяющегося круга. М. Бёрнс сделала подсчет статей, опубликованных в двух научных журналах, World Englishes и English Today, и обнаружила, что в течение периода 1998-2001 гг. эти журналы опубликовали 47 статей о вариантах Расширяющегося круга. В 2001-2018 гг. число статей о вариантах Расширяющегося круга уже было 318. Общее число статей составило 365, они охватывали 79 стран и 11 регионов, причем «львиная доля» статей (Berns 2019: 12) имела отношение к Восточной Азии, особенно Китаю (около 100 работ) и Японии (20 работ). Описание русского варианта английского языка обнаружено в 19 статьях, из которых бо́льшая часть была напечатана в специальном выпуске журнала World Englishes (Proshina 2005). В целом, М. Бёрнс подчеркнула, что варианты Расширяющегося круга «во многих аспектах остаются белыми пятнами» ${ }^{3}$ (Berns 2019: 13).

В самом деле, доказательством ее утверждения могут быть энциклопедические справочные издания, известные как handbooks. Первая книга такого рода о вариантах английского языка, "The Handbook of World Englishes", опубликованная в 2006 г. (Kachru, Kachru \& Nelson 2006), содержала только три главы о региональных вариантах Расширяющегося круга - восточноазиатских, южноамериканских и европейских (из 16 глав, описывающих локализованные варианты английского языка в мире). Второе издание "Тhе Handbook of World Englishes" издательства Wiley-Blackwell (Nelson, Proshina \& Davis 2020) имеет уже пять глав, рассказывающих об английском языке

2 “ThoughtCo" - один из современных справочно-образовательных сайтов, контент которого готовится крупнейшими специалистами в своей области. См. https://www.thoughtco.com/ about-us (дата обращения: 16.07.2020).

3 Здесь и далее перевод наш. - 3.П. 
Восточной Азии, Китая, Южной Америки, Европы и России. Пять глав о вариантах Восточной Азии, Китая, славянских государств, Колумбии и Европы включены в книгу “The Routledge Handbook of World Englishes” (Kirkpatrick 2010). Только один регион (Центральной Америки) Расширяющегося круга освещен в кембриджском издании "The Cambridge Handbook of World Englishes" (Schreier, Hundt \& Schneider 2020), и лишь три - в соответствующем оксфордском издании "The Oxford Handbook of World Englishes" (Filppula, Klemola \& Sharma 2017). Семь региональных вариантов стали объектом описания "The Routledge Handbook of English as a Lingua Franca" (Jenkins, Baker \& Dewey 2018). Несмотря на то что книга под редакцией Э. Тамбу называется “The Three Circles of English" (т.е. Три круга английского языка) (Thumboo 2001) и ее целью было описание различных вариантов английского языка, которые категоризируются в модели Б. Качру, только четыре главы этой книги ориентированы на Расширяющийся круг как таковой. Очень мало информации о Расширяющемся круге можно найти также в словаре вариантов английского языка "A Dictionary of Varieties of English" (Hickey 2014).

Немногочислены и работы о конкретных вариантах Расширяющегося круга. Европейские варианты исследованы в работах Ясоне Сенос и Ульрике Есснер (Cenoz \& Jessner 2000), Манфреда Гёрлаха (Görlach 2001, 2002), Марджи Бёрнс, Кис де Бот и Уве Хасебринк (Berns et al. 2007), Анник де Хоувер и Антдже Уилтон (Houwer \& Wilton 2011), Элисон Эдвардс (Edwards 2016), Д.С. Бородиной (Borodina 2018). Восточноазиатские варианты английского языка исследованы 3.Г. Прошиной (Proshina 2001, 2020), Кингсли Болтоном (Bolton 2003), Джеймсом Стэнлоу (Stanlaw 2004), Л.П. Бондаренко (2007), Джозефом Ло Бьянко, Джейн Ортон и Гао Ихун (Bianko, Orton \& Gao 2009), Т.А. Иванковой (Ivankova 2009), Филипом Саржантом (Seargeant 2009, 2011), Сюй Чжичаном (Хu 2010), В.Л. Завьяловой (Zavyalova 2011), Дэвидом Грэддолом (Graddol 2013), Гленном Хадикином (Hadikin 2014), Чо Цзиньюнь (Сho 2017), Кристофером Дженксом и Джерри Вон Ли (Jenks \& Lee 2017).

Русский вариант английского языка, будучи очень дискуссионным вопросом, стал основной темой коллективной монографии Russian English: History, Functions, and Features (Proshina \& Eddy 2016), а также целого ряда статей (Gritsenko 2014, Proshina 2006, 2014b, Proshina \& Rivlina 2018, 2020, Rivlina 2013, 2015a, 2015b, Ustinova 2005, 2006) и диссертаций (Eddy 2007, Lawrick 2011, Lazaretnaya 2012). Некоторые авторы, несмотря на то что они не пользуются термином «русский вариант английского языка» на самом деле способствовали развитию дискуссии об этом варианте, его культурном базисе (Kabakchi 1998, 2002, 2015) и языковых чертах (Savitsky \& Kurovskaya 2004, Schennikova 2017, Shishkina 1996).

Подготовка данного тематического выпуска журнала мотивирована необходимостью обсудить сущность вариантов Расширяющегося круга и факторов, которые способствуют их развитию и отличают их друг от друга и от вариантов Внутреннего и Внешнего кругов, что, тем не менее, до сих пор 
не признается многими говорящими на этих вариантах и даже лингвистами, которые, с одной стороны, принимают разделение вариантов английского языка, предложенное Б. Качру, но с другой, выступают против того, что варианты Расширяющегося круга имеют право называться собственно вариантами.

\section{2. Парадигма вариантов английского языка и ее отличия от других теорий}

Перед тем как представить статьи данного выпуска журнала, нам бы хотелось напомнить читателю основные положения контактной вариантологии английского языка, известной за рубежом как парадигма Word Englishes (WE), и связь этой парадигмы с другими теориями, которые в действительности отпочковались от данной концепции.

Парадигма вариантов английского языка, появившаяся в 1960-х годах (Kachru 1961, Беляева \& Потапова 1961) и получившая развитие с тех пор, при этом ее теоретическая основа была заложена в 1980-1990-х годах (Kachru 1986, Kachru \& Smith 1985, Smith 1987, Smith \& Forman 1997, см. также Bolton 2020), - это революционная теория (Proshina 2014), поскольку она в корне изменила традиционные взгляды на языковое доминирование Британской империи, перевернула социолингвистические идеи и кардинально преобразовала педагогические представления, которые проникли в практику обучения английскому языку и его изучения. Подытоживая основные положения этой парадигмы, следует акцентировать следующие тезисы:

- Английский язык перестал быть монолитным и однородным языком. Будучи плюрицентричным (что обусловлено историческими, политикоэкономическими и культурно-информационными причинами), он дифференцировался на большое число вариантов (world Englishes).

- Каждый вариант опирается на свою лингвокультуру, а это означает, что он способен выражать культурную идентичность своих пользователей и имеет черты, перенесенные из их родных языков и/или языков, с которыми вариант вступает в регулярный контакт.

- Вариант - социолингвистическое явление. Он характеризуется чертами, которые свойственны определенному усредненному речевому сообществу, но не обязательно проявляются в речи каждого члена этого сообщества - использование языка каждым говорящим зависит от уровня языковой компетенции, сферы использования, стиля коммуникации и индивидуальных предпочтений.

- Благодаря лингвокультурному основанию, определяющему каждый вариант, все варианты английского языка равны в своей легитимности. В самом первом номере журнала World Englishes его редакторы, основатели журнала, заявили: 
Редакционная коллегия считает, что пользователи английским языком как родным, так и неродным - равные партнеры в дискуссии о пользователях английским языком и о преподавании его на международном уровне. Таким образом, журнал $W E$ является средством, которое может использоваться для того, чтобы делиться знаниями и опытом пользователей как западных, так и незападных стран на благо всех пользователей английским языком... Таким образом, акроним $W E$ как нельзя лучше символизирует основную философию журнала и цели его редколлегии (Kachru \& Smith 1985: 211)

- Варианты Внешнего и Расширяющегося кругов используются как дополнительные или вспомогательные (Smith 1976) коммуникативные инструменты. Может показаться, что функции развивающихся вариантов ограничены, но чем дольше развивается вариант, тем больше функций он приобретает. Б. Качру (1986: 92) пишет о диапазоне распространения вариантов английского языка в «культурных, образовательных и коммерческих контекстах» и о глубине их социального принятия и использования в «различных слоях общества». Такое динамическое развитие теперь стало явным во всех вариантах.

Эти инновационные черты имеют большую значимость для лингвистики, особенно социолингвистики, литературоведения, культурологии и прикладной лингвистики, под которой мы понимаем не только область методики преподавания и изучения языка, как это обычно характерно для «англофонной литературы» (Knapp \& Antos 2009: vii), но также так называемую «практическую прикладную лингвистику» в толковании этого термина О. Баком (Back 1970), как это имеет место и в России, т.е. как «применение данных и выводов лингвистики в практических областях, имеющих отношение к языку, таких как методика обучения, перевод и т.п.» (Knapp \& Antos 2009: vii). Одним словом, в этих чертах проявляется междисциплинарность новой парадигмы, что обусловливает гораздо бо́льшую сферу ее функционирования, чем теории английского как иностранного языка (EFL), которая используется в методике преподавания английского языка.

Концепция WE дала начало развитию новых направлений исследования, называемых новыми парадигмами - английского как международного языка (EIL) и английского как лингва франка (ELF), в которых находят развитие некоторые аспекты, свойственные вариантам английского языка. Оба эти направления ориентируются на преподавание английского языка. Они противостоят методике английского как иностранного языка (EFL), в основе которой лежит обучение моноцентрической или бицентрической модели английского языка, базирующейся на британском варианте и культуре Великобритании и/или американском варианте английского языка, его культуре и ценностях, обслуживаемых этим вариантом.

В отличие от методического понятия «английский как иностранный язык», термин «английский как международный язык», предложенный Ларри 
Смитом (Smith 1976) и далее разработанный Фарзадом Шарифианом (Sharifian 2009) и другими учеными (Alsagoff 2012, Marlina \& Giri 2014, Matsuda 2012, 2017, МсКау 2002), фокусируется на необходимости ознакомления студентов с различными вариантами английского языка, которые могут потребоваться им в будущей коммуникации в реальных жизненных ситуациях:

На самом деле, представление об английском как международном языке отвергает мысль о том, что в качестве лингва франка для межкультурной коммуникации выбирается какой-то особый вариант. Теория английского как международного языка подчеркивает, что английский язык со всеми его множественными вариантами является языком международной и потому межкультурной коммуникации (Sharifian 2009: 2).

Если в основе концепта «английский как международный язык» лежит признак разнообразия вариантов английского языка, то похожий термин «международный английский» (International English) - предполагает противоположное явление. Он ассоциируется с якобы унифицированным стандартным английским, который облегчает международную коммуникацию (Todd \& Hancock 1987, Trudgill \& Hannah 1994), подобно идее Р. Квирка о «ядерном английском» (Quirk 1982), и используется в формальных контекстах (однако, как будет показано ниже, это абстрактный идеал, реализуемый в живой речевой практике, по меньшей мере, с локальным акцентом или с другими контекстно-специфическими чертами варианта). Такое понимание международного английского совпадает с определением Питера Стревенса (Strevens 1983): международный английский - это «особенный диалект английского языка, который является единственным нелокализованным диалектом, глобального распространения, без значительного варьирования, повсеместно воспринимаемый как приемлемая цель обучения английскому языку, на котором можно говорить с самыми разными акцентами» (Strevens 1983: 88). На самом деле сегодня невозможно говорить об одном и том же стандарте английского языка для всех вариантов - они быстро изменяются, и в них происходит процесс стандартизации (Hickey 2013). Судя по определению П. Стревенса, 'английский как международный язык' (EIL) и 'международный английский' (IE) оказываются антонимическими концептами: 'английский как международный язык' ориентируется на разнообразие и дифференциацию, т.е. на варианты, а 'международный английский' - на единство и однородность, т.е. инвариант.

Термин «английский как лингва франка» (ELF) был возрожден Аланом Фиртом (Firth 1990, 1996) и обозначает «модус операнди», не являющийся родным языком ни для одного из коммуникантов (Firth 1996: 255). Как следует из этого определения, носители языка исключаются из этой концептуализации, что не может не вызвать вопросов, поскольку те, кто говорит на родном для них английском языке, должны адаптировать свою речь в условиях 
межкультурного общения. Поэтому в настоящее время более распространенным стало определение Барбары Зайдльхофер: английский как лингва франка (ELF) - это «любое использование английского языка среди говорящих с разными первыми языками, для которых английский является выбранным средством коммуникации, часто единственно возможным» (Seidlhofer 2011: 7). Это определение включает коммуникантов трех кругов (однако, до сих пор английский как лингва франка ассоциируют преимущественно с Расширяющимся кругом). Дефиниция английского как лингва франка, предложенная Б. Зайдльхофер, содержит важную идею о данном концепте: английский как лингва франка - это использование, или функция любого варианта английского языка. У него нет статуса самого варианта, это просто прагматический аспект варианта. Любой вариант английского языка, в том числе варианты Внутреннего круга, обладают этой функцией, реализуемой главным образом в межкультурном общении. Но кроме этой функции, у вариантов английского языка (world Englishes) есть также много других функций.

Не вызывает удивления, что, когда преподаватели говорят об английском как лингва франка, они обращают внимание, главным образом, на три объекта: стратегии коммуникации, на проблемы взаимопонимания и осознание различий.

Во-первых, стратегии коммуникации направлены на достижение взаимного приспособления коммуникантов через такие адаптивные процессы, как избыточность речи, регуляризация, усиление экспрессии, экспликация, поправки, переформулирование, повтор, кодовое смешение, обговаривание значения и многие другие (Cogo \& Dewey 2012, Mauranen \& Ranta 2010, Meierkord 2012, Vettorel 2018). Исследования этих процессов в значительной степени проводятся с использованием корпусов. Вот почему бесспорен вклад этих исследователей в корпусную лингвистику (например, VOICE, ViennaOxford International Corpus of English; ELFA, English as a Lingua Franca in Academic Settings; CASE, Corpus of Academic Spoken English; ACE, Asian Corpus of English; RACE, Russian-Asian Corpus of English; BELF, English as Business Lingua Franca).

Во-вторых, общей проблемой для исследователей английского как лингва франка (ELF), английского как международного языка (EIL) и вариантов английского языка (WE) стало исследование взаимопонимания в межнациональной коммуникации. Еще в начале появления контактной вариантологии английского языка эта проблема была сформулирована Ларри Смитом и исследователями, работавшими с ним (Nelson 2011, Smith 1992, Smith \& Bisazza 1982, Smith \& Rafiqzad 1979, Smith and Nelson 2020), как трехаспектное явление: понимание разговорных и письменных форм речевой продукции (intelligibility), понимание значения того, что написано или сказано (comprehensibility), и понимание смыслла текста (interpretability) - прагматический компонент, ассоциируемый с фоновыми знаниями коммуникантов и позволяющий им понимать цель используемого языка. 
Третья проблема - осознание различий, - широко обсуждаемая исследователями английского как лингва франка (Bayyurt \& Sifakis 2015, Lopriore \& Vettorel 2015, Sifakis et al. 2018, Sung 2018, Wang 2015), объединяет их с исследователями английского как международного языка и вариантов английского языка. Как показано выше, разнообразие стало ключевым словом в исследованиях английского как международного языка. Варианты английского языка выделяются на основе отличительных признаков и функций; именно благодаря им они дифференцируются как варианты. С методической точки зрения ознакомление с разнообразием того, как люди говорят по-английски из-за различий в лингвокультурах, должно стать «информированным выбором» (Jenkins 2007: 22), необходимым для эффективной межкультурной коммуникации.

Одной из проблем, которая стала камнем преткновения между сторонниками направления ELF и сторонниками контактной вариантологии, стало отношение между понятиями 'английский как лингва франка' и 'вариант'. Несмотря на то что сегодня признан тезис о том, что английский как лингва франка «не существует как система» (Canagarajah 2007: 926), что он «появляется из взаимодействия и благодаря ему» (Meierkord 2004: 129, также Kecskes 2019) и что это абстракция, концепт функции, а не живого варианта как такового (Berns 2009: 196), время от времени обнаруживаются работы (например, Breiteneder 2009, Mackenzie 2014, Jenkins 2017), описывающие фонетические, синтаксические и другие уровни английского как лингва франка и показывающие, что авторы этих работ трактуют ELF как структурированный вариант (по крайней мере, в обобщенном виде, что представляет это понятие как абстракцию, а не живой феномен). Надо говорить о вариантах английского языка, функционирующих как лингва франка.

\section{3. Рассеивание сомнений относительно Расширяющегося круга}

В то время как варианты Внутреннего круга, старые и новые (как, например, новозеландский, австралийский и канадский), и многие варианты Внешнего круга признаны всеми и уже хорошо описаны на сегодняшний день, варианты английского языка Расширяющегося круга еще не получили единодушного признания, особенно среди своих собственных пользователей. Как правило, причинами этого называют отсутствие кодификации этих вариантов, но, если посмотреть на проблему глубже, можно увидеть, что на самом деле неприятие вариантов Расширяющегося круга обусловлено отсутствием признания их лингвокультурной специфичности.

Что касается кодификации, которая обычно понимается как процесс, приводящий к стандартизации языка, можно с уверенностью утверждать, что стандартизированы все варианты как явления языка, но их речевое проявление может либо следовать нормам, либо нарушать их. Вслед за Д. Дэйвисом (Davis 2010) мы используем термин «стандартизированный английский язык» (standardized English), а не «стандартный английский» (standard English), 
подчеркивая, что во всех вариантах английского языка, в том числе вариантах Внутреннего круга, происходят динамические изменения.

Говоря о типах языковых норм, Б. Качру (Kachru 1985) разделил их на три вида, соответствующие «трем кругам»: Внутренний круг включает эндонормативные варианты, которые обычно служат нормообеспечивающими моделями для других вариантов английского языка; варианты Внешнего круга обнаруживают наиболее динамичные процессы модификации норм и потому считаются норморазвивающими, а варианты Расширяющего круга являются нормозависимыми и используют экзонормы, выработанные и кодифицированные в других вариантах английского языка, но не только Внутреннего круга - если возникает необходимость, пользователи английским языком в Расширяющемся круге могут также использовать стандарты Внешнего круга. Вариативность экзонорм, особенно построенных на британской и американской моделях, обусловливает их частое смешение, и это объясняет специфику использования стандартизированного варианта Расширяющегося круга.

Что касается речепроизводства на вариантах Расширяющегося круга, Б. Качру объясняет сущность этого процесса в виде билингвальной шкалы (Kachru 1983). Любой вариант, получаемый в результате контакта с родными языками пользователей, свидетельствует о билингвизме его пользователей, который можно представить как функциональный континуум, зависящий от языковой компетенции пользователей и стиля их дискурса. Акролектная речь характерна для формального дискурса пользователей с высокой степенью компетентости; мезолектная речь проявляется главным образом в неформальном дискурсе образованных пользователей или в формальном и неформальном дискурсе коммуникантов с меньшей степенью владения языком, и базилектная речь, в результате которой появляется гибридный и даже пиджинизированный вид дискурса, характерна для необразованных пользователей (Proshina 2017: 150-152).

Очевидно, что стандартизация не может считаться основным аргументом для принятия варианта, который может существовать как в стандартизированной, так и нестандартизированной формах и который включает не только акролект, но также мезолект и базилект. Признание варианта происходит тогда, когда его пользователи осознают, что их вариант языка выражает их лингвокультурную идентичность и что он может быть первичным или вторичным средством ее выражения. Вариант, на котором они говорят и пишут, выражает их культуру, ценности, менталитет и картину мира. Эта концептуально-культурная часть идентичности выражается прежде всего через лексику и синтаксис (реалии, коллокации и синтаксические структуры). Кроме этих средств выражения, языковая часть идентичности также передается на фонетическом уровне (фонетический акцент) и грамматическом (грамматические категории, как, например, дискретность в выражении множественного числа существительных - equipments, furnitures - формы, отмечаемые 
в азиатских вариантах английского языка). Лингвистические признаки варианта образуются в результате переноса черт первого языка пользователей, а также в результате вербализации их менталитета. Например, даже в акролектном варианте русского английского можно различить русскую интонацию, оглушение конечных согласных, частое отсутствие аспирации, иногда специфичное произнесение отдельных звуков (таких как $t h, w, r$ ), благодаря чему легко определяется русский акцент. На грамматическом уровне для речи русских на английском языке типично выдвижение в начальную позицию прямого дополнения (This book I haven't read yet.), отсутствие или необычное использование артиклей (the complex ethnical structure of the population determines peculiarity of the gender interaction), избегание употребления перфектных времен (I am living in this city since childhood), замена препозитивной атрибутивной цепочки постпозитивными предложными сочетаниями в атрибутивной функции (Old English period > period of Old English), предпочтение безличных предложений со структурным подлежащим (It is expected that she will come вместо She is supposed to come). Многие другие черты дискурса на русском варианте английского языка описаны в коллективной монографии под редакцией 3. Г. Прошиной и А. А. Эдди (Proshina \& Eddy 2016).

Далеко не все пользователи вариантом демонстрируют в своей речи все черты, типичные для варианта. Как уже отмечалось, число дистинктивных признаков варианта в индивидуальной речи пользователя зависит от его языковой компетентности, контекста ситуации, психологического состояния и желания говорящего следовать образовательной модели как экзонорме.

Признание варианта - долгий процесс. Необходимо время для того, чтобы английский язык в определенном регионе утвердился как локальный вариант английского языка. Даже для вариантов Внутреннего круга, например, австралийского английского, потребовался переходный период для превращения из «английского языка в Австралии» в австралийский вариант английского языка (Fritz 2007), который был признан как собственно вариант только в 1970-х годах, когда австралийцы преодолели свое «культурное подобострастие», и их культурный национализм проложил дорогу утверждению их языковой и культурной идентичности.

Социальное и психологическое осознание своей лингвокультурной идентичности, выраженной через вариант, а также проявляемой посредством образовательной кодификации (Kachru 1985), приводит к признанию дистинктивных признаков варианта. Многие из вариантов Расширяющегося круга все еще находятся в процессе такого признания. Признание, несомненно, придет с расширением функционального использования вариантов Расширяющегося круга. Сегодня они используются уже не только в функции межкультурного общения в качестве языка-посредника (лингва франка). Они также выполняют информативную функцию в бизнесе, рекламе, средствах массовой информации, науке. Они выполняют инструментальную функцию, выступая, 
например, в качестве английского как средства обучения (EMI). Варианты английского языка Расширяющегося круга проявляют также креативную функцию (в транслингвальной, или контактной литературе, массовой культуре, в игровом использовании в каламбурах и т.д. - см., например, работу Б. Зайдльхофер (Seidlhofer 2010) о функциях английского языка и сферах его использования в Европе).

В завершение необходимо подчеркнуть, что варианты Расширяющегося круга реально существуют, и независимо от того, насколько близко их пользователи приблизились к экзонормативной модели, варианты будут характеризоваться своими дистинктивными чертами, поскольку они служат вторичным средством лингвокультурной идентичности. Вариант - это типичное собрание дискурсивных событий и продуктов, отличающихся языковыми признаками и культурным основанием.

Вариант не является имитацией кодифицированной модели обучения, также как он не является набором неправильных речевых образцов интеръязыка. Варианты Расширяющегося круга, как и любые другие варианты английского языка, используются и образованными коммуникантами, высоко компетентными и бегло говорящими на английском языке - коммуникантами, которых Б. Качру назвал функциональными носителями своих вариантов (Kachru 1998, Smith 2008).

Изучение вариантов английского языка должно составлять неотъемлемую часть программы английского языка как международного. Осознание разнообразия вариантов английского языка представляет бесспорную значимость в обучении языку и его изучении, а также в устном и письменном переводе. Прикладной лингвистике еще предстоит многое получить от исследований по контактной вариантологии. Знание дистинктивных признаков других вариантов, а также специфики их систем латинизации (как, например, китайской системы пиньинь) облегчит коммуникацию на разных вариантах английского языка, а также будет способствовать межвариантному переводу.

Признание своего собственного варианта как средства выражения своей культуры и своего менталитета, а также понимание места своего варианта среди других вариантов английского языка в мире обеспечивает психологический комфорт в межкультурной коммуникации благодаря принципам инклюзивности и равенства вариантов. Знание типичных черт своего собственного варианта важно для улучшения уровня своей языковой компетенции.

\section{4. Краткое содержание данного выпуска журнала}

В одной из своих работ М. Бёрнс (Berns 2005: 92) писала о «рассвете вариантов Расширяющегося круга». Публикация этого номера журнала доказывает, что рассвет постепенно перерос в позднее утро, хотя полуденный пик еще не достигнут. 
Описав, что побудило нас к изданию этого тематического выпуска, и осветив основные положения контактной вариантологии как науки о вариантах английского языка в современном мире (WE) и отпочковавшихся от нее парадигм английского как международного языка (EIL) и английского как лингва франка (ELF), мы бы хотели выразить благодарность всем авторам, приславшим свои материалы и сделавшим этот выпуск интересным и информативным.

Как можно видеть из оглавления, статьи, представленные в этом выпуске, рассматривают азиатские (японский и китайский), европейский (немецкий) и русский варианты английского языка. Они освещают общие проблемы вариантов Расширяющегося круга, их статус, черты и функции (Э. Киркпатрик, В.Л. Завьялова, Чж. Сюй и Д. Чжан, А.А. Ривлина, Е.С. Гриценко и А.В. Аликина, Ю. Давыдова). В некоторых статьях обсуждаются методические и педагогические проблемы, связанные с преподаванием вариантов английского языка в глобальном и локальных масштабах (Дж. Д'Анджело и С. Икэ, Н. Хино). Одна статья (Г.Н. Ловцевич и А. А. Соколов) представляет исследование лексикографического аспекта вариантов с позиций исследователей Расширяющегося круга. Кроме научно-исследовательских статей, данный номер журнала включает две рецензии (Е.В. Маринина, Е.С. Лебедева), имеющие непосредственное отношение к теме вариантной дифференциации английского языка.

Все обсуждаемые проблемы показаны в международной перспективе, поскольку авторы этого выпуска работали с материалом разных стран и синтезировали свои эмпирические исследования с глубоким теоретическим обоснованием. Мы надеемся, что вопросы, поднятые в статьях этого выпуска, окажутся интересными для читателя, будут стимулировать мысль, послужат основой для последующих исследований и для практического использования.

(C) Zoya G. Proshina and Cecil L. Nelson, 2020 (c) creative

This work is licensed under a Creative Commons Attribution 4.0 International License https://creativecommons.org/licenses/by/4.0/

\section{REFERENCES / СПИСОК ЛИТЕРАТУРЫ}

Alsagoff, Lubna, Sandra L. McKay, Guangwei Hu \& Willy A. Renandya (eds.). 2012. Principles and Practices for Teaching English as an International Language. New York \& London: Routledge.

Back, Otto. 1970. Was bedeutet und was bezeichnet der Ausdruck "Angewandte Sprachwissenschaft"? [What does Applied Linguistics mean and characterize?] Die Sprache. Zeitschrift für Sprachwissenschaft 16 (1). 21-53. 
Bayyurt, Yasemin \& Nicos C. Sifakis. 2015. ELF-aware in-service teacher education. In Hugo Bowles \& Alessia Cogo (eds.), International Perspectives on English as a Lingua Franca: Pedagogical Insights, 117-135. London: Palgrave-MacMillan.

Beare, Kenneth. 2020. How Many People Learn English? ThoughtCo, Feb. 11. URL: thoughtco.com/how-many-people-learn-english-globally-1210367 (accessed 16 June 2020).

Beliayeva, Tatiana M. \& Irina A. Potapova. 1961. Anglijskij yazyk za predelami Anglii [English Beyond England]. Leningrad: Uchpedgiz Publ.

Berns, Margie. 2005. Expanding on the Expanding Circle: Where do WE go from here? World Englishes 24 (1). 85-93.

Berns, Margie. 2009. English as lingua franca and English in Europe. World Englishes 28 (2). $192-199$.

Berns, Margie. 2019. Expanding on the Expanding Englishes of the Expanding Circle. World Englishes 38 (1-2). 8-17.

Berns, Margie, Kees de Bot \& Uwe Hasebrink (eds.). 2007. In the Presence of English: Media and European Youth. New York: Springer.

Bianco, Joseph Lo, Jane Orton \& Yihong Gao (eds.). 2009. China and English: Globalization and the Dilemmas of Identity. Bristol: Multilingual Matters.

Bolton, Kingsley. 2003. Chinese Englishes: A Sociolinguistic History. Cambridge: Cambridge University Press.

Bolton, Kingsley. 2020. World Englishes: Current debates and future directions. In Cecil L. Nelson, Zoya G. Proshina \& Daniel R. Davis (eds.), The Handbook of World Englishes. $2^{\text {nd }}$ edn., 743-760. Hoboken, NJ: Wiley-Blackwell.

Bondarenko, Ludmila P. (eds.). 2007. Slog i ritm anglijskoj rechi v stranah Vostochnoj i YugoVostochnoj Azii (Kitaj, Respublika Koreya, Yaponiya, V'etnam, Tailand) [Syllable and Rhythm of English Speech in the Countries of Eastern and South-Eastern Asia (China, Republic of Korea, Japan, Vietnam, Thailand)]. Vladivostok: Far Eastern Univ. Press.

Borodina, Dar'ya S. 2018. Transnacional'nyj anglijskij yazyk $v$ anglo-skandinavskom bilingvizme [Transnational English in English-Scandinavian Bilingualism]. Simferopol: ARIAL Publ.

Breiteneder, Angelika. 2009. English as a Lingua Franca in Europe: A Natural Development. Saarbrücken: VDM Verlag Dr. Müller.

Canagarajah, Suresh. 2007. Lingua Franca English, Multilingual Communities, and Language Acquisition. The Modern Language Journal 91. Focus Issue. 923-939.

Cenoz, Jasone \& Ulrike Jessner (eds.). 2000. English in Europe: The Acquisition of a Third Language. Bristol: Multilingual Matters.

Cho, Jinhyun. 2017. English Language Ideologies in Korea: Interpreting the Past and Present. Cham, Switzerland: Springer.

Cogo, Alessia \& Martin Dewey. 2012. Analysing English as a Lingua Franca: A Corpus-driven Investigation. London \& New York: Continuum.

Davis, Daniel R. 2010. Standardized English: The history of the earlier circles. In Andy Kirkpatrick (ed.), The Routledge Handbook of World Englishes, 17-36. London \& New York: Routledge.

Eddy, Anna. 2007. English in the Russian context: A macrosociolinguistic study. Michigan: Wayne State University. (PhD dissertation).

Edwards, Alison. 2016. English in the Netherlands: Functions, Forms and Attitudes. Amsterdam: John Benjamins.

Filppula, Markku, Juhani Klemola \& Devyani Sharma (eds.). 2017. The Oxford Handbook of World Englishes. Oxford: Oxford University Press. 
Firth, Alan. 1990. 'Lingua franca' negotiations: Towards an interactional approach. World Englishes 9 (3). 269-280.

Firth, Alan. 1996. The discursive accomplishment of normality. On 'lingua franca' English and conversation analysis. Journal of Pragmatics 26. 237-259.

Fritz, Clemens W.A. 2007. From English in Australia to Australian English: 1788-1900. Frankfurt am Main: Peter Lang.

Görlach, Manfred (eds.). 2001. A Dictionary of European Anglicisms. Oxford: Oxford University Press.

Görlach, Manfred (eds.). 2002. English in Europe. Oxford: Oxford University Press.

Graddol, David. 2013. Profiling English in China: The Pearl River Delta. Cambridge: Cambridge English Language Assessment.

Gritsenko, Elena S. 2014. Anglijskij yazyk kak semioticheskij resurs v sovremennoj rossijskoj povsednevnosti [English as a semiotic resource in everyday Russian communication]. The Humanities and Social Studies in the Far East 42 (2). 27-31.

Hadikin, Glenn. 2014. Korean English: A Corpus-driven Study of a New English. Amsterdam: John Benjamins.

Hickey, Raymond (ed.). 2013. Standards of English: Codified Varieties Around the World. Cambridge: Cambridge University Press.

Hickey, Raymond. 2014. A Dictionary of Varieties of English. Malden: Wiley-Blackwell.

Houwer, Annick De \& Antje Wilton (eds.). 2011. English in Europe Today: Sociocultural and Educational Perspectives. Amsterdam \& Philadelphia: John Benjamins.

Ivankova, Tat'yana A. 2009. Anglijskij yazyk v Kitae: Regional'nye osobennosti [English in China: Regional Features]. Vladivostok: Far Eastern University Press.

Jenkins, Jennifer. 2007. English as a Lingua Franca: Attitude and Identity. Oxford: Oxford University Press.

Jenkins, Jennifer. 2017. English as a lingua franca in the Expanding Circle. In Markku Filppula, Juhani Klemola \& Devyani Sharma (eds.), The Oxford Handbook of World Englishes, 549-566. Oxford: Oxford University Press.

Jenkins, Jennifer, Will Baker \& Martin Dewey (eds.). 2018. The Routledge Handbook of English as a Lingua Franca. London \& New York: Routledge.

Jenks, Christopher J. \& Jerry Won Lee. 2017. Korean Englishes in Transnational Contexts. Cham, Switzerland: Palgrave Macmillan.

Kabakchi, Victor V. 1998. Osnovy angloyazychnoj mezhkulturnoj kommunikacii [Fundamentals of English Intercultural Communication]. St. Petersburg: Russian State Pedagogical University.

Kabakchi, Victor V. 2002. The Dictionary of Russia: English-English dictionary of Russian cultural terminology. St. Petersburg: Soyuz.

Kabakchi, Victor V. 2015. Realii russkoj kul'tury v Bol'shom Oksfordskom slovare [Russian culture-loaded words in the Oxford English Dictionary]. The Humanities and Social Studies in the Far East 44 (1). 16-22.

Kachru, Braj B. 1961. An Analysis of Some Features of Indian English: A Study of Linguistic Method. Unpublished doctoral dissertation. University of Edinburgh.

Kachru, Braj B. 1983. Models for non-native Englishes. In Larry E. Smith (ed.), Readings in English as an International Language, 69-86. Oxford: Pergamon Press.

Kachru, Braj B. 1985. Standards, codification and sociolinguistic realism. The English language in the outer circle. In Randolph Quirk \& Henry G. Widdowson (eds.), English in the World: Teaching and Learning the Language and Literatures, 11-30. Cambridge: Cambridge University Press. Reprint: Bolton, Kingsley \& Braj B. Kachru (eds.). 2006. World Englishes: Critical Concepts in Linguistics 3. 241-269. London; New York: Routledge. 
Kachru, Braj B. 1986. The Alchemy of English: The Spread, Functions, and Models of NonNative Englishes. Oxford: Pergamon Press. Reprint: Urbana \& Chicago: University of Illinois Press. 1990.

Kachru, Braj B. (ed.). 1992 [1982]. The Other Tongue: English across Cultures. Urbana \& Chicago: University of Illinois Press.

Kachru, Braj B. 1998. English is an Asian language. Links and Letters 5. 89-108.

Kachru, Braj B., Yamuna Kachru \& Cecil L. Nelson (eds.). 2006. The Handbook of World Englishes. Malden, MA: Blackwell.

Kachru, Braj B. \& Larry E. Smith. 1985. Editorial. World Englishes 4 (2). 209-212.

Kecskes, Istvan. 2019. English as a Lingua Franca: The Pragmatic Perspective. Cambridge: Cambridge University Press.

Kirkpatrick, Andy (ed.). 2010. The Routledge Handbook of World Englishes. London \& New York: Routledge.

Knapp, Karlfried \& Gerd Antos. 2009. Introduction to the Handbook series. In Karfried Knapp \& Barbara Seidlhofer (eds.), with Henry G. Widdowson. Handbook of Foreign Language Communication and Learning, v-vii. Berlin, New York: Mouton de Gruyter.

Lawrick, Elena. 2011. English in Russian academe: Uses and perceived significance. West Lafayette: Purdue University. (PhD dissertation).

Lazaretnaya, Olesya. 2012. English as a lingua franca in Russia: A sociolinguistic profile of three generations of English users. University of Lisbon. (PhD dissertation).

Levada-Center. 2014. Vladeniye inostrannymi yazykami [Proficiency in Foreign Languages]. May 28. URL: https://www.levada.ru/2014/05/28/vladenie-inostrannymi-yazykami/ (accessed 26 June 2020)

Lopriore, Lucilla \& Paola Vettorel. 2015. Promoting awareness of Englishes and ELF in the English language classroom. In Hugo Bowles \& Alessia Cogo (eds.), International Perspectives on English as a Lingua Franca: Pedagogical Insights, 13-34. London: Palgrave-MacMillan.

Mackenzie, Ian. 2014. English as a Lingua Franca: Theorizing and Teaching English. London \& New York: Routledge.

Marlina, Roby \& Ram A. Giri (eds.). 2014. The Pedagogy of EIL: Perspectives from Scholars, Teachers, and Students. Cham, Switzerland: Springer.

Matsuda, Aya (ed.). 2012. Principles and Practices of Teaching English as an International Language. Bristol: Multilingual Matters.

Matsuda, Aya (ed.). 2017. Preparing Teachers to Teach English as an International Language. Bristol: Multilingual Matters.

Mauranen, Anna \& Elina Ranta (eds.). 2010. English as a Lingua Franca: Studies and Findings. Newcastle-upon-Tyne: Cambridge Scholars.

McKay, Sandra. 2002. Teaching English as an International Language. Oxford: Oxford University Press.

Meierkord, Christiane. 2004. Syntactic variation in interactions across international Englishes. English World-Wide 25 (1). 109-132.

Meierkord, Christiane. 2012. Interactions across Englishes: Linguistic Choices in Local and International Contact Situations. Cambridge: Cambridge University Press.

Nelson, Cecil L. 2011. Intelligibility in World Englishes: Theory and Application. New York \& London: Routledge.

Nelson, Cecil L., Zoya G. Proshina \& Daniel R. Davis (eds.). 2020. The Handbook of World Englishes. $2^{\text {nd }}$ edn. Hoboken, NJ: Wiley-Blackwell.

Proshina, Zoya G. 2001. Anglijskij yazyk i kul'tura narodov Vostochnoj Azii. [The English Language and Culture of East Asian People]. Vladivostok: Far Eastern Univ. Press. 
Proshina, Zoya G. (ed.). 2005. Russian Englishes: Special issue. World Englishes 24 (4). 437-532.

Proshina, Zoya G. 2006. Russian English: Status, attitudes, problems. The Journal of Asia TEFL 3 (2). 79-101.

Proshina, Zoya G. 2014a. Language revolution behind the cultural curtain. World Englishes 33 (1). 1-8.

Proshina, Zoya G. 2014b. Russian English: Myth or reality? Intercultural Communication Studies 23 (1). 14-27.

Proshina, Zoya G. 2017. Kontaktnaya variantologiya angliyskogo yazyka: Problemy teorii. World Englishes Paradigm. Moscow: Flinta - Nauka Publ.

Proshina, Zoya G. 2020. Mezhkul'turnaya kommunikaciya: Anglijskij yazyk i kul'tura narodov Vostochnoj Azii. [Intercultural Communication: The English Language and Culture of East Asian People]. $2^{\text {nd }}$ edn. Moscow: Yurait Publ.

Proshina, Zoya G. \& Anna A. Eddy (eds.). 2016. Russian English: History, Functions, and Features. Cambridge: Cambridge University Press.

Proshina, Zoya G. \& Alexandra A. Rivlina. 2020. Anglijskij yazyk v Rossii kak variant i kak yazykovoj resurs [English in Russia as a variety and a language resource]. In Maria B. Rarenko (ed.), Anglijskij yazyk na territorii Soedinyonnogo Korolevstva Velikobritanii $i$ Severnoj Irlandii $i$ za ego predelami [The English Language in the United Kingdom of Great Britain and Northern Ireland and Beyond Its Territory], 73-89. Moscow: INION RAN.

Proshina, Zoya G. \& Alexandra A. Rivlina 2018. Mock Russian English: shutlivo-parodijnoye ispol'zovaniye russkogo varianta anglijskogo yazyka v stranakh Vnutrennego kruga [Mock Russian English: Playful and parodic use of the Russian variety of English in the Inner Circle countries]. Vestnik Moskovskogo Universiteta. Ser. 19: Lingvistika i mezhkul'turnaya kommunikaciya [Moscow State University Bulletin. Series 19. Linguistics and Intercultural Communication] 3. 18-30.

Quirk, Randolph. 1982. International communication and the concept of nuclear English. In Christopher Brumfit (eds.), English for International Communication, 15-28. Oxford: Pergamon Press.

Rivlina, Alexandra A. 2013. O nekotorykh osobennostyakh i lingvisticheskikh problemakh processa formirovaniya massovogo russko-anglijskogo bilingvizma [Some features and linguistic problems in forming mass Russian-English bilingualism]. The Humanities and Social Studies in the Far East 37 (1). 61-66.

Rivlina, Alexandra A. 2015a. Bilingual creativity in Russia: English-Russian language play. World Englishes 34 (3). 436-455.

Rivlina, Alexandra A. 2015b. Vzaimodejstviye russkogo yazyka s anglijskim v nazvaniyakh rossijskikh Internet-saitov [Russian and English interaction in the names of Russian Internet sites]. The Humanities and Social Studies in the Far East 45 (1). 32-36.

Savitsky, Vladimir M. \& Anna E. Kurovskaya. 2004. Nacional'naya specifika anglijskoj rechi (grammaticheskij aspect) [National specifics of English speech (grammatical aspect)]. Moscow: Pearson Education, Moscow City Pedagogical University.

Schennikova, Natalia V. 2017. Strukturno-semanticheskiye i Funkcional'nye Kharacteristiki Russkogo Idioma Anglijskogo Yazyka [Structural, Semantic, and Functional Characteristics of the Russian Implementation of the English Language]. Samara: Samara State University. (Doctoral dissertation).

Schneider, Edgar W. 2017. Models of English in the world. In Markku Filppula, Juhani Klemola \& Devyani Sharma (eds.), The Oxford Handbook of World Englishes, 35-57. Oxford: Oxford University Press. 
Schreier, Daniel, Marianne Hundt \& Edgar W. Schneider (eds.). 2020. The Cambridge Handbook of World Englishes. Cambridge: Cambridge University Press.

Seargeant, Philip. 2009. The Idea of English in Japan: Ideology and the Evolution of a Global Language. Bristol: Multilingual Matters.

Seargeant, Philip (ed.). 2011. English in Japan in the Era of Globalization. New York: Palgrave Macmillan.

Seidlhofer, Barbara. 2010. Lingua franca English: The European context. In Andy Kirkpatrick (ed.), The Routledge Handbook of World Englishes, 355-371. London \& New York: Routledge.

Seidlhofer, Barbara. 2011. Understanding English as a Lingua Franca. Oxford: Oxford University Press.

Sharifian, Farzad. 2009. English as an International Language: An overview. In Farzad Sharifian (ed.), English as an International Language. Perspectives and Pedagogical Issues, 1-18. Bristol: Multilingual Matters.

Shishkina, Tatyana G. 1996. Russkij “accent" v pis'mennom perevode (morfologicheskij uroven') [The Russian 'Accent' in Written Translation (Morphological Aspect)]. Moscow: Lomonosov Moscow State University. (PhD dissertation).

Sifakis, Nicos S., Lucilla Lopriore, Martin Dewey \& Yasemin Bayyurt. 2018. ELF-awareness in ELT: Bringing together theory and practice. Journal of English as a Lingua Franca 7 (1). 155-209.

Smith, Larry E. 1976. English as an international auxiliary language. RELC Journal 7 (2). Reprint: Larry E. Smith (ed.). 1983. Readings in English as an International Language, 1-5. Oxford: Pergamon Press.

Smith, Larry E. (ed.). 1987. Discourse Across Cultures: Strategies in World Englishes. London: Prentice Hall.

Smith, Larry E. 1992. Spread of English and issues of intelligibility. In Braj B. Kachru (ed.), The Other Tongue. English across Cultures. $2^{\text {nd }}$ edn., 75-90. Urbana \& Chicago: University of Illinois Press.

Smith, Larry E. 2008. Familiar issues from a World Englishes perspective. In Zoya G. Proshina (ed.), Kulturno-yazykovye kontakty [Culture and Language Contacts], 67-73. Vladivostok: Far Eastern University Press. Reprint: Bulletin of Peoples' Friendship University of Russia. Series of Education Issues: Languages and Speciality. 2016. 1. 14-18.

Smith, Larry E. \& John A. Bisazza, 1982. The comprehensibility of three varieties of English for college students in seven countries. Language Learning 32 (2). Reprint: Larry E. Smith (ed.). 1983. Readings in English as an International Language, 59-68. Oxford: Pergamon Press.

Smith, Larry E. \& Michael L. Forman (eds.). 1997. World Englishes 2000. Honolulu: University of Hawaii Press.

Smith, Larry E. \& Khalilullah Rafiqzad. 1979. English for cross-cultural communication: The question of intelligibility. TESOL Quarterly 13 (3). Reprint: Larry E. Smith (ed.). 1983. Readings in English as an International Language, 49-58. Oxford: Pergamon Press.

Smith, Larry E. \& Cecil L. Nelson. 2020. World Englishes and issues of intelligibility. In Cecil L. Nelson, Zoya G. Proshina \& Daniel R. Davis (eds.), The Handbook of World Englishes. $2^{\text {nd }}$ edn., 430-446. Hoboken, NJ: Wiley-Blackwell.

Stanlaw, James. 2004. Japanese English: Language and Culture Contact. Hong Kong: Hong Kong University Press.

Strevens, Peter. 1983. What is "Standard English"? In Larry E. Smith (ed.), Readings in English as an International Language, 87-93. Oxford: Pergamon Press. 
Sung, Chit Cheung Matthew. 2018. Out-of-class communication and awareness of English as a Lingua Franca. ELT Journal 72 (1). 15-25.

Thumboo, Edwin (ed.). 2001. The Three Circles of English: Language Specialists Talk about the English Language. Singapore: UniPress.

Todd, Loretto \& Ian Hancock. 1987. International English Usage. New York: New York University Press.

Trudgill, Peter \& Jean Hannah. 1994. International English: A Guide to the Varieties of Standard English. $3^{\text {rd }}$ edn. London: Edward Arnold.

Ustinova, Irina P. 2005. English in Russia. World Englishes 24 (2). 239-251.

Ustinova, Irina P. 2006. English and emerging advertising in Russia. World Englishes 25 (2). 267-278.

Vettorel, Paolo. 2018. ELF and communication strategies: Are they taken into account in ELT materials? RELC Journal 49 (1). 58-73.

Wang, Ying. 2015. Language awareness and ELF perceptions of Chinese university students. In Hugo Bowles \& Alessia Cogo (eds.), International Perspectives on English as a Lingua Franca: Pedagogical Insights, 96-116. London: Palgrave-MacMillan.

Wei, Rining \& Jinzhi Su. 2012. The statistics of English in China: An analysis of the best available data from government sources. English Today 28 (3). 10-14.

$\mathrm{Xu}$, Zhichang. 2010. Chinese English: Features and Implications. Hong Kong: Open University of Hong Kong Press.

Zav'yalova, Viktoriya L. 2011. Anglijskij yazyk v Kitae: Osobennosti prosodicheskogo stroya. [English in China: Specifics of the Prosodic Structure]. Vladivostok: Marine State University Press.

Article history:

Received: 30 May 2020

Revised: 15 July 2020

Accepted: 17 July 2020

\section{История статьи:}

Дата поступления в редакцию: 30 мая 2020

Дата принятия к печати: 17 июля 2020

\section{Bionotes:}

Zoya G. PROSHINA is Professor in the Faculty of Foreign Languages and Area Studies, Lomonosov Moscow State University, Russia, and Professor in the Department of Linguistics and Intercultural Communication Studies, Far Eastern Federal University, Vladivostok, Russia. She was President of the International Association for World Englishes (2011-2012). She authored Kontaktnaya variantologiya angliyskogo yazyka: World Englishes Paradigm (2017), Angliyskiy yazyk i kultura Vostochnoy Azii [The English Language and Culture of East Asia] (2020), Teoriya perevoda (Translation Theory] (2019), and co-edited, with Anna Eddy, the volume Russian English: History, Functions, and Features (2016); and with Cecil L. Nelson and Daniel Davis, the $2^{\text {nd }}$ edn. of The Handbook of World Englishes (2020). She was guest-editor of a special issue on Russian Englishes of the World Englishes journal (2005).

\section{Contact information:}

Lomonosov Moscow State University, 1, bld. 13, Leninskiye Gory, Moscow, 119991, Russia 
e-mail: proshinazoya@yandex.ru

ORCID ID: 0000-0002-0570-2349

Cecil L. NELSON is Professor Emeritus of Linguistics in the Department of Languages, Literatures and Linguistics at Indiana State University, USA. He was Review Editor of the journal World Englishes and was President of the International Association for World Englishes (2015-2017). He is the author of Intelligibility in World Englishes: Theory and Application (2011), a co-author, with Yamuna Kachru, of World Englishes in Asian Contexts (2006), a co-editor, with Braj B. Kachru and Yamuna Kachru, of The Handbook of World Englishes (2006), and a co-editor, with Zoya Proshina and Daniel Davis, of the $2^{\text {nd }}$ edition of The Handbook of World Englishes (2020).

\section{Contact information:}

Indiana State University, Terre Haute, United States

e-mail:cj3nelson@yahoo.com

\section{Сведения об авторах:}

Зоя Григорьевна ПРОШИНА - доктор филологических наук, профессор кафедры теории преподавания иностранных языков, факультет иностранных языков и регионоведения, Московский государственный университет имени М.В. Ломоносова. В 2011-2012 была Президентом Международной ассоциации исследователей вариантов английского языка. Является автором книг: "Контактная вариантология английского языка: Вопросы теории: World Englishes Paradigm” (2017), «Английский язык и культура Восточной Азии» (2020), «Теория перевода» (2019). Вместе с А.А. Эдди выступила редактором коллективной монографии "Russian English: History, Functions, and Features" (2016); вместе с Сесилом Нельсоном и Дэниэлом Дэйвисом была соредактором 2-го изд. "The Handbook of World Englishes" (2020).

\section{Контактная информация:}

МГУ имени М.В. Ломоносова, Факультет иностранных языков и регионоведения. 119991, Россия, Москва, Ленинские горы, 1, стр. 13.

e-mail:proshinazoya@yandex.ru

ORCID ID: 0000-0002-0570-2349

Сесил Л. НЕЛЬСОН - Почетный профессор лингвистики, кафедра языков, литератур и лингвистики, Университет штата Индиана, США. Являлся зав. отдела рецензий журнала World Englishes, Президентом Международной ассоциации исследователей вариантов английского языка (2015-2017). Автор книги Intelligibility in World Englishes: Theory and Application (2011); соавтор - вместе с Ямуной Качру World Englishes in Asian Contexts (2006); с Браджем и Ямуной Качру The Handbook of World Englishes (2006); с Зоей Г. Прошиной и Дэниэлом Дэйвисом 2-го изд. The Handbook of World Englishes (2020).

\section{Контактная информация:}

Indiana State University, Terre Haute, Indiana, USA

e-mail:cj3nelson@yahoo.com 